\title{
Health evaluation of donkeys: parasite control methods and a model for challenge infections
}

\section{Avaliação sanitária de jumentos: métodos de controle parasitário e um modelo para o desafio das infecções}

\author{
Marcelo Beltrão Molento ${ }^{1 *}$ (D); Vinicius Longo Ribeiro Vilela² \\ ${ }^{1}$ Universidade Federal do Paraná, Laboratório de Parasitologia Clínica Veterinária, Curitiba - PR, Brazil \\ ${ }^{2}$ Instituto Federal da Paraíba, Laboratório de Parasitologia Veterinária, Sousa - PB, Brazil
}

\begin{abstract}
Donkeys, mules, and asses are domestic animals of worldwide distribution, found in all regions of Brazil. Although more health data is needed from these species, some sectors of today's society are exploring alternatives to use these animals for milk production and the use of donkeys in social events and onotherapy. Donkeys (Equus asinus) are used in many everyday activities, but the animals need better welfare conditions. Although it is well known that endoparasite infections (i.e. cyathostomins, Strongylus spp., Parascaris sp.) can harm the clinical condition of the animals, there are limited clinical and laboratory supporting data, including registered therapeutic drugs for their control. The objective of the present work was to review the existing literature about parasite infections of donkeys, including their clinical implications, and the drug efficacy test to help practitioners improve their health management programs. To assist with that, we have developed a questionnaire to identify the risk factors of donkey farming, which is presented here in English and in Portuguese. Lastly, the present article also includes an original simulation using the susceptible-infectedrecovered (SIR) model with low, moderate, and severe scenarios to help visualize the risk of parasite infections. The SIR model was based on the disease condition of donkeys in Brazil, using transient interaction levels from 0.0015 to 0.0025 , infectivity levels from 0.10 to 0.40 , and distinct recovery rates $(\mathrm{R})$ from 0.01 to 0.08 . As milk production is an expanding new activity worldwide, we want to emphasize that the first comprehensive studies must take into account differences in animal age, breed, and body condition score, local climate, pasture quality, day of sampling, and the period of lactation within the lactation curve to measure the health condition of donkeys. These data are considered important and will then be correlated to the parasite egg/oocyst (EPG or OoPG) counts in the feces using coproparasitological protocols (McMaster and Mini-FLOTAC), and even DNA-based techniques, to establish a novel data bank for donkeys. Target selective treatment has been proposed to be used as a routine in horses and will also be implemented in donkeys. This technique aims to reduce the number of anthelmintic treatments and, consequently, lessen parasite selection for resistance. The dynamic variations found by the SIR model are discussed in the text and should be taken into account when deciding the best health management implementation and parasite control programs. We think that more studies are needed to evaluate the basic physiological performance of donkeys in tropical areas to better understand their thermal adaptation, assuming that the animals are kept under acceptable clinical, nutritional, and housing conditions to express their resilient behavior. Cases of neglect and ill-treatment of animals must also be studied in infected conditions as well as their negative impacts. These strategies reinforce the concept of holistic farming with the possibility to improve specific informations, thereby improving the welfare of the donkeys.
\end{abstract}

Keywords: Equids. Parasite infections. Milk production. Welfare. Brazil.

\section{RESUMO}

Jumentos, mulas e burros são animais domésticos de distribuição mundial, encontrados em todas as regiões do Brasil. Muito embora exista uma grande necessidade de produzir mais dados sobre estas espécies, atualmente alguns setores estão buscando alternativas de exploração para estes animais, como a produção de leite e o uso deles em atividades sociais e onoterapia. Jumentos (Equus asinus) participam de várias atividades sociais, porém os animais necessitam de melhores condições de manejo e bem-estar. Embora as endoparasitoses (ex. ciatostomíneos, Strongylus spp., Parascaris sp.) possam causar grave condição clínica para estes animais, dados clínicos e laboratoriais são escassos, incluindo a falta de produtos específicos para seu controle. O objetivo do presente trabalho foi revisar a literatura existente sobre infecções parasitárias 
em jumentos, incluindo as implicações clínicas e os testes de eficácia de drogas, visando auxiliar os profissionais e os seus programas de manejo sanitário. Para auxiliar nesta demanda, desenvolvemos um questionário para identificar os fatores de risco na criação de jumentos. Este documento está apresentado na versão em inglês e em português. Finalizando, o presente artigo também inclui uma simulação original de prevalência de parasitos usando o modelo susceptívelinfectado-recuperado (SIR), com cenários de infecção leve, moderada e severa, para avaliar sobre o risco de infecção parasitária. O modelo SIR usou dados da doença que ocorre em jumentos no Brasil, com níveis transitórios de interação de 0,0015 a 0,0025, infectividade de 0,10 a 0,40 e de recuperação (R) de 0,01 a 0,08 . Como a atividade de produção de leite de jumentos é nova e em expansão no mundo, os primeiros estudos da condição sanitária em jumentos devem levar em consideração diferenças de idade, raça e escore de condição corporal, clima, qualidade do pasto, dia da coleta e período de lactação durante a curva de lactação. Estes dados são consideravelmente importantes e serão correlacionados com a contagem de ovos ou oocistos (OPG e OoPG) de parasitos nas fezes, usando protocolos coproparasitológicos (McMaster e Mini-FLOTAC), e até de técnicas de DNA, para estabelecer um banco de dados inédito para jumentos. $\mathrm{O}$ tratamento seletivo já foi proposto como rotina em equinos e pode ser implementado em jumentos. Esta técnica visa reduzir o número de tratamentos anti-helmínticos e consequentemente diminuir a seleção de resistência parasitária. A variação dos dados obtidos com o modelo SIR são discutidos no texto e devem ser considerados no momento da tomada de decisão sobre as melhores práticas de manejo e programas de controle parasitário. Julgamos que mais estudos são necessários para avaliar o comportamento fisiológico dos animais em clima tropical, para melhor compreender a sua adaptação térmica e seu desempenho, assumindo que os animais sejam mantidos em condições nutricionais, clínica e de alojamento aceitáveis, para expressar seu comportamento resiliente. Casos de negligencia e maus-tratos também devem ser estudados em animais infectados, assim como seus efeitos negativos. Todas estas estratégias reforçam o conceito de uma pecuária holística, com a possibilidade de desenvolver um maior conhecimento específico, melhorando o grau de bem-estar de jumentos.

Palavras-chave: Equídeos. Infecção parasitária. Produção de leite. Bem-estar. Brasil.

\section{Correspondence to:}

Marcelo Beltrão Molento

Universidade Federal do Paraná, Laboratório de Parasitologia

Clínica Veterinária

R. dos Funcionários, 1540

CEP: 80035-050, Curitiba - PR, Brazil

e-mail: molento@ufpr.br

Received: August 29, 2020

Approved: January 22, 2021

How to cite: Molento MB, Vilela VLR. Health evaluation of donkeys: parasite control methods and a model for challenge infections. Braz J Vet Res Anim Sci. 2021;58(special issue):e174275. https://doi.org/10.11606/issn.1678-4456. bjvras.2021.174275

\section{Introduction}

Donkeys are domestic animals with a worldwide distribution. In Brazil, there are an estimated 900,000 donkeys of different breeds, mainly Pêga, Brasileiro, and Nordestino. Of these, 90\% are the Nordestino breed, which are located in the Northeast region, where the animals significantly contribute to local economies (Instituto Brasileiro de Geografia e Estatística, 2012). Most of the animals are used for traction work, transport of people, and to prepare the soil for crop plantation (Paz et al., 2013; Upjohn et al., 2014). Even though donkeys have a high capacity to survive in adverse environments, showing a great tolerance to work under harsh conditions, the animals need specialized technical assistance to guarantee good health and life quality (Antunes et al., 2013). Recently, there has been an increase in their presence in animal-assisted therapy for children and dairy production (Borioni et al., 2012; Dai et al., 2017; Karatosidi et al., 2013; Rangel et al., 2015). Moreover, some sectors are looking for other ways to exploit donkeys and this is especially true in the semi-arid areas of Brazil and other similar countries in Latin America (LATAM), the Caribbean, Africa, and Asia (Karatosidi et al., 2013; Upjohn et al., 2014).

The use of donkeys for traction occurs on the outskirts of major cities and reveals a considerable lack of adequate food and health for the animals by breeders, thus creating a low welfare condition for the animals. The cultural idea of donkeys' rusticity assumes that these animals do not need to be vaccinated, dewormed, have veterinary assistance, or even receive adequate nutrition. This is incorrect, and the animals' food condition is precarious in some farms, where the vast majority of the animals only ingest a mixture of pasture and corn, without any mineral supplementation (Passantino, 2011). The author reported that it is necessary to offer an adequate condition to donkeys that are in low welfare conditions.

Donkeys are considered to have advantages over horses, but knowledge about donkey health is scarce and cannot compare to the volume of scientific publications that exist for horses (Araújo et al., 2014). Only during the past four 
decades, we have determined 4,838 articles about donkeys and 129.804 articles on horses (scopus.com). Of these, only 741 (15\%) articles were published in the area of donkey parasitology. Brazilian publications on parasite species presented data from Theilleria sp., Babesia spp., Toxoplasma gondii, Trypanosoma vivax, and some other gastrointestinal parasites, as cyathostomin species (Maestrini et al., 2020). Therefore, there is a great need for more parasitologicalbased data on these animal species. Such information could be important for donkeys used for milk production and also in social activities (Borioni et al., 2012).

The main objective of the present work was to review and discuss the existing literature about parasite infections of donkeys. We intend to warn about the need for more technical and health information for this species, using the latest tools to monitor parasite infections. To assist with this, we have included a fully developed questionnaire to identify the risk factors of donkey farming. A parallel exercise is suggested as we run an original simulation SIR model to determine parasite challenge in three different infectivity scenarios.

\section{Donkeys Used for Dairy and Social Activities}

Donkey milk shows some similarity to human milk in composition (protein: humans from 0.96 to $1.63 \%$, mare: 1.65 to $3.0 \%$, and donkey: $1.4 \%$ ) as demonstrated by Holmes et al. (1947), having also good nutritional levels of calcium, sodium, and protein (Aspri et al., 2019; Fantuz et al., 2012). Donkey milk has been considered as an exceptional alternative for feeding infants and children with intolerance to cow milk protein or multiple food allergies (Carroccio et al., 2000; Dai et al., 2017; Mansueto et al., 2013). Aspri et al. (2019) reported that more than 34 farms in Italy are using donkeys for dairy and are producing a considerable amount of data regarding milk quality, milk components, nutrition, and, very importantly, the welfare condition of these animals (Animal Welfare Indicators, 2015). Therapy activity using equids is a reality, mainly in Italy. The onotherapy has been carried out with 14 donkeys of the Amiatina breed on a farm near Pisa, Toscana region. This project and others are supported by the European Community and have technicians from several European countries such as Denmark and Sweden to monitor the development of children (Wise, 2020). Similar projects have also started in Brazil by the Brazilian Breeding Association of the Pêga Donkey (ABCJPêga, 2020).

\section{Parasitic Diseases in Donkeys: a First Look Into the Data Collection}

Data on management practices, type of production, and concentration of milk components (i.e. calcium, phosphorus) have been studied (Dai et al., 2017; Fantuz et al., 2012; Ragona et al., 2016), but although gastrointestinal parasitosis can cause evident clinical conditions in donkeys, clinical and laboratory data are scarce (Matthews \& Burden, 2013). As dairy animals are raised closer to humans in a semi-intensive system, there is a concern about an increase in the prevalence of parasitic infections. Higher pasture contamination will be the main cause of this condition, thereby imposing a direct risk to the welfare of these animals (Dai et al., 2019). Considering the importance of the above issues and the lack of information, the first studies on the health of donkeys for milk production should take into account characteristics of age, breed, body condition score, local climate, quality of pasture and protein in the diet, somatic cell count, milk collection day and lactation period, including the use of mathematical models to establish the lactation curves. Mathematical models were already applied in donkeys for dairy (Bordonaro et al., 2013) and dairy cows (Naderi, 2018).

Therefore, we must prioritize the quality of consecutive data collection in Brazil and other LATAM countries that will allow us to establish solid protocols, improving animal health. The data shall be correlated with parasite egg or oocyst (EPG, OoPG) counts, using standard (McMaster) or more modern (Mini-FLOTAC) coprological methods (Castro et al., 2017). Technology transfer is essential between academia and veterinarians, and hands-on training courses are fundamental, as practitioners will carry on this work, establishing a gold standard health platform for donkeys.

\section{Clinical and Parasitic Problems in Donkeys}

In developing countries, one of the main health problems of donkeys are parasitic diseases (Svendsen, 2000) and studies of gastrointestinal parasites described a high diversity of helminth species in donkeys, such as small and large strongyles (Maestrini et al., 2020), tapeworms (Anoplocephalidae), ascarid (Parascaris equorum), pinworm (Oxyuris equi) and lungworm (Dictyocaulus arnfieldi) (Attia et al., 2018; Gianfaldoni et al., 2020; Matthews \& Burden, 2013). Of these, Strongyles are primarily responsible for parasitic diseases on donkeys, not only due to its general health problems, but also for the gastrointestinal disorders, including colic, and the potentially fatal condition of acute larval cyathostominosis (Disassa et al., 2015; Ferreira et al., 2014; Love et al., 1999; Tavassoli et al., 2016). High infection rates caused by small strongyles can also produce anemia, dry hair coat, apathy, diarrhea, and reduced nutrient absorption, leading to weight loss and decrease productivity in equids (Molento, 2005; Oryan et al., 2015). From a clinical point of view, an anemic or digestive syndrome will depend on the 
dominant parasite species and its degree of pathogenicity, which characterizes infections by gastrointestinal parasites in donkeys (Matthews \& Burden, 2013).

In the Brazilian semiarid region, Costa et al. (2018) evaluated the occurrence and intensity of endoparasites in equids for traction, where 51\% (49/96) were donkeys. In these animals, $85.7 \%$ (42/49) and 8.2\% (4/49) were positive for Strongylidae and Giardia sp., respectively. The identification of the larvae revealed that $78 \%$ were small strongyles (cyathostomins), 8\% Strongylus equinus, 6\% Trichostrongylus axei, 5\% S. edentatus, and $3 \%$ S. Vulgaris. The authors found no statistically significant differences in EPG values with sex, age, and percentages of hematocrit. Maestrini et al. (2020) found similar data (sex, age) when looking for larval identification in donkeys from three different farm typologies in Tuscany, Italy. They found a $100 \%$ prevalence of small strongyles in all farms, with the Cylicocyclus spp. and Cylicostephanus spp. the most (92 to $100 \%$ ) prevalent genera.

Cyathostomins are the most common parasites in equids and can produce several different clinical syndromes (larval cyathostominosis), such as acute protein loss, recurrent diarrhea, rapid weight loss, subcutaneous edema, colic, and, occasionally, death due to toxic shock. The infected animals may show catarrhal inflammation, hemorrhagic typhlitis, or fibrinous enteritis in the cecum or other parts of the large intestine that may result in intestinal ulcers and possible intestinal wall perforation (Oryan et al., 2015). Besides, small strongyles are probably the causative agents of nonstrangulating intestinal infarcts and caecal tympany (Love, 2002). The damage caused by large strongyles (Subfamily: Strongylinae) produce lesions in the gut wall as they feed and larvae make destructive migrations in various tissues of the animal body. S. Vulgaris is particularly dangerous because the larvae develop in the mesenteric arterial system causing arthritis and thrombosis with serious clinical consequences (Ogbourne \& Duncan, 1985).

One important risk to the control of endoparasites refers to which doses of antiparasitic drugs donkeys would receive in treatment, as there is no indication in the commercial horse products (Elsheikha, 2019). The lack of officially registered drugs for donkeys drives breeders to use extralabel medication for horses and even for cattle (Imam et al., 2010; Trawford \& Tremlett, 1996). This decision is almost obligatory, making it possible to have donkeys with less than the expected efficacy $(<90 \%)$, causing inadequate worm reduction, according to Molento et al. (2008). It is even possible for animals to have toxic reactions by overdosing, due to differences in the pharmacokinetics of the drugs among different host species (Grosenbaugh et al., 2011).
Also, parasite resistance to medications may arise soon after a few rounds of antiparasitic use (Peregrine et al., 2014). The overuse of some of these drugs (i.e. fenbendazole, ivermectin), has led parasite populations to be selected for resistance (Molento et al., 2008). This is already happening in donkeys as the animals are receiving more attention and good care (Grosenbaugh et al., 2011).

Canever et al. (2013), reported that fenbendazole obtained low efficacy in all 11 horse breeding farms in the South of Brazil, due to the excess use of the product. After this, the authors are now recommending, as a precaution, that the drug should not be given to horses to avoid the risk of serious clinical conditions, such as embolic colic caused by Parascaris sp. until new efficacy tests can be performed. Gokbulut et al. (2014) measured the plasma disposition of two formulations of pyrantel pamoate (PYR) in donkeys in a controlled trial. Seven donkeys received pyrantel paste or granule formulations at a horse dosage of $20 \mathrm{mg} / \mathrm{kg}$ of body weight. EPG was determined and the drug concentration was analyzed by high-performance liquid chromatography. Although there was no statistical difference between the terminal half-lives and maximum retention time values, the maximum concentration and area under the curve values of the paste formulation was significantly lower, when compared to the granule formulations. Following the treatments, both PYR formulations had an efficacy above 95\%. In all studied donkeys, coproculture revealed the presence of cyathostomins and S. Vulgaris (Gokbulut et al., 2014). Papini et al. (2020), found that ivermectin at $200 \mathrm{mcg} / \mathrm{kg}$ of body weight, a similar dose for horses, had an efficacy of $100 \%$ up to six weeks posttreatment against strongyle parasites in Amiatina donkeys in Pisa, Italy.

We consider that all the above conditions, including the differences in EPG and the use of drug combination, are of great concern and more work must be performed to determine specific pharmacological information for donkeys. As mentioned above, donkeys are regarded as resilient animals (Grosenbaugh et al., 2011) and we suggest that animals should be treated under the target selective regime, once we have the proper tools (i.e. clinical and laboratory exams/fecal egg count), to individually evaluate the animals (Molento, 2009). We have developed a questionnaire that is available in English and in Portuguese, to be used in equids (Figure 1). The objective is to gather farm information and focus on management strategies for parasite control (Canever et al., 2013). The data can be interpreted as the first level of information before testing for drug efficacy. 
(OPTIONAL)

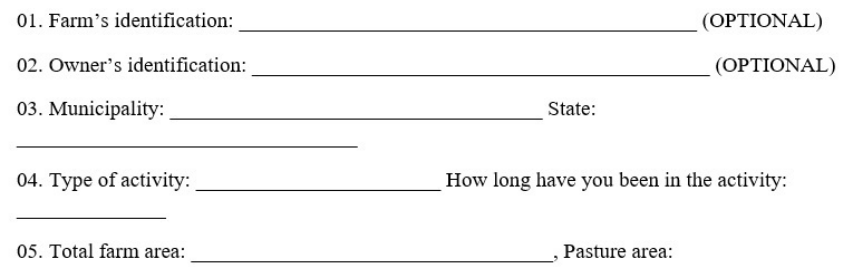

06. Are there are other animals: (Horses, sheep, goats, cattle, poultry, pigs):

07. Breed of the animals: Quantity:

08. Are the animals in paddocks? ( ) Yes ( ) No ( ) Only at night (semi-feedlot)

09. Number of paddocks: Dimensions:

10. Are the feces removed from the paddocks? ( ) Yes ( ) No

11. Is there fertilization of pasture? ( ) Yes ( ) No

12. Do you compost the dung before throwing the feces on the pasture? ( ) Yes ( ) No

13. Do you know the signs of worm infection in animals? ( ) Yes ( ) No

14. Is manure removed from the stable or stall? ( ) Daily ( ) Irregular Periods

15. Do you rotate paddocks? ( ) Yes ( ) No

16. Do you quarantine the newly acquired animals? ( ) Yes ( ) No

17. Has any type of parasite been observed in animals or in their feces? ( ) Yes ( ) No

18. Do you treat all animals with dewormer at the same time? ( ) Yes ( ) No

19. How often are anthelmintics applied?

( ) Monthly ( ) Annual ( ) Every 2 or 3 months ( ) Every 4 or 6 months ( ) don’t use

( ) After fecal tests ( ) In animals with helminthiasis signs ( ) Pre-delivery strategy / foals

20. Is the amount of worms controlled after application? ( ) Yes ( ) No

21. Has the product effectiveness test against parasites been carried out? ( ) Yes ( ) No

22. What is the main product used on the property?

23. Do you change anthelmintics frequently? ( ) Yes ( ) No

24. Do you follow the veterinarian's instructions for anthelmintic use? ( ) Yes ( ) No

25. How do you choose the antiparasitic medication?

26. How is the weight estimation of the animals made? ( ) Weighing ( ) Weight tape ( ) Visual

27. Have you ever done parasitic tests (EPG) on animals? ( ) Yes ( ) No

28. Do you have technical assistance for animals? ( ) Yes ( ) No

29. Where do you get new information?

30. Are you aware of the problem of parasite resistance to anthelmintics? ( ) Yes ( ) No

Name of responsible technician:

City: _ Date: ___ _ _

Project number:

Figure 1 - Questionnaire to be used in equid farms focusing on management strategies for local parasite control. (a) English and (b) Portuguese version

\section{Testing for Drug Efficacy/Resistance: a Potent Tool in Donkeys}

To correctly evaluate drug efficacy, using the fecal egg count reduction test (FECRT), groups of 6 to 10 naturally infected donkeys should be used with individual EPG greater than 200 eggs, when using a McMaster chamber or 50 when using Mini-FLOTAC (Castro et al., 2017). Castro et al. (2017) determined the consistency of these two techniques in horses, using commercially available anthelmintic products (b) MONITORAMENTO PARASITÁRIO EM EQUÍDEOS

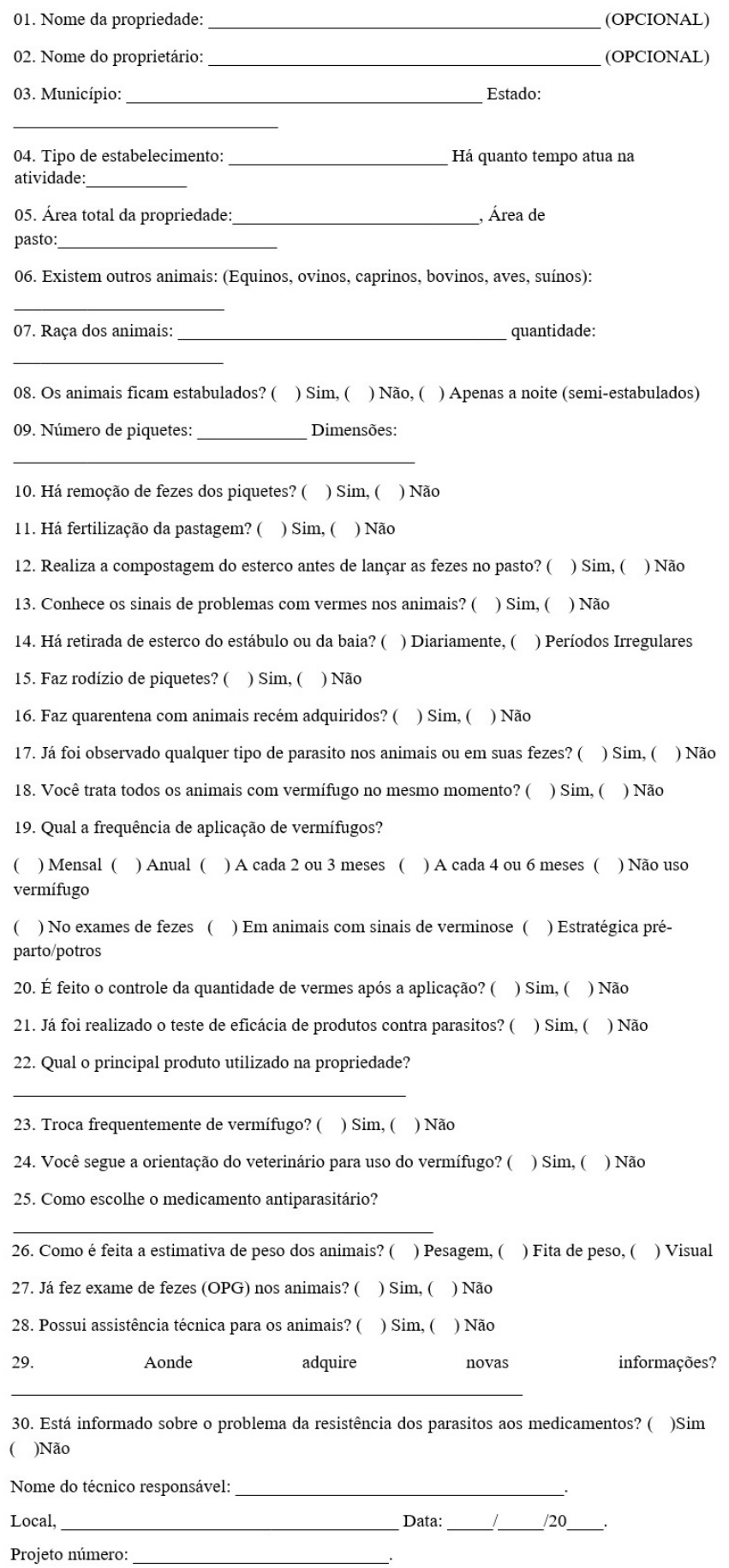


great efficacy values (100\%) for more than 40 days, even to 72 days (90\%) using extra-label ivermectin.

Coproculture should also be performed when doing a FECRT to identify the genus/species of the third stage larvae for the parasites present in the animals, using a newly released identification key (Santos et al., 2018), and complementing with the morphological key from Bevilaqua et al. (1993). The larval identification may have regional parasite population differences that we need to know to better recommend a control plan. When performing a parasitological necropsy, veterinarians should focus their attention on the small and large intestines, as well as liver and lungs, to identify the species of adult parasites using the parasite morphological key published by Lichtenfels et al. (2008). Along with the EPG, DNA can be extracted from the individual or pooled parasite samples (adults or larvae) for future analysis of single nucleotide polymorphism (SNP) to determine drugresistant marker candidate gene/s (Ishii et al., 2017). In the future, this technology may be a substitute for other more laborious and expensive in-lab techniques.

\section{The Mechanistic SIR Model and the Proposed Dynamics of Parasite Infection}

It is known that most of the nematode parasites have a one-host direct life-cycle, and any biological analyses of parasite infection must account for many dynamic interactions with the host and the local environment (i.e. climate, parasite infection, and reproduction rate, health programs, and host susceptibility). These interactions reveal that the biological threshold of pathogens may be determined by the infection of the first susceptible host, following the expected host interaction and disease infectivity (Heesterbeek \& Roberts, 1995). Moreover, any host-parasite relationship is not homogeneous when one observes animal susceptibility and parasite invasion within the breed, making any assumption a complex issue. The susceptible-infected-recovered, SIR epidemic model uses ordinary equations based on the rate of infection in susceptible individuals. The SIR model gives the possibility to predict pathogen evolution and can measure the rate of health protocols (Vynnycky \& White, 2010).

We have applied the SIR model for donkeys to determine three levels of parasite infectivity (low, moderate, severe), using 1000 animals, as suggested by Molento et al. (2020). At the beginning, the assumptions were interaction levels from 0.0015 to 0.0025 , infectivity from 0.10 to 0.40 , recovery rate $(\mathrm{R})$ from 0.01 to 0.08 , and "time" equals to zero plus one $(t=0+1)$ (Table 1$)$. The low infectivity was characterized by low pasture contamination with low
Table 1 - Established conditions for the SIR model for parasite infection in donkeys

\begin{tabular}{ccccc}
\hline Model & $\begin{array}{c}\text { N. of } \\
\text { animals }\end{array}$ & $\begin{array}{c}\text { Infectivity } \\
\text { level }\end{array}$ & $\begin{array}{c}\text { Interaction } \\
\text { level }\end{array}$ & $\begin{array}{c}\text { Recuperation } \\
\text { level }\end{array}$ \\
\hline Condition A & 1000 & 0.10 & 0.0015 & 0.08 \\
Condition B & 1000 & 0.20 & 0.0020 & 0.04 \\
Condition C & 1000 & 0.40 & 0.0025 & 0.02 \\
\hline
\end{tabular}

animal infectivity (average of $50 \mathrm{EPG}$ in the animals). The first model also included little interaction between infected animals, suggesting a high degree of disease recuperation. The moderate contamination condition was described as medium pasture contamination and animal infectivity (average of $500 \mathrm{EPG}$ ). We have also proposed a moderate interaction between infected animals with a moderate recuperation ratio. The third condition represents a severe disease transmission with a high number of infected animals and an extremely low number of recoveries. The data from Costa et al. (2018) was used to run the SIR model based on the disease condition of donkeys in Brazil.

The results demonstrated the different levels of animal infectivity and recovery (Figure 2a-c). The SIR model also confirmed that once the infection level is low (Figure 2a), recovery would be much faster when compared to the high-risk level (Figure 2c). All these dynamic variations are straightforward to interpret and should be taken into account when deciding herd management implementation and strategic control programs. The biological data of larval concentration on pasture, the ratio of larval ingestion, adult parasite development in the host, rate of parasite reproduction and egg production, parasite lifespan, and the return of host susceptibility shall be considered when interpreting the complexity of the host-parasite relationship. Drug treatment was not included in the model and can be regarded as "human-caused" perturbation, which would then affect the mean duration of infection and the actual number of parasites (to zero), altering all the model dynamics.

\section{The Future of Donkey Medicine and Parasite Control}

Donkey medicine is facing a new era of reports, especially in Italy, the UK, Brazil, and countries in Africa and the Middle East (Aspri et al., 2019; Maestrini et al., 2020; Matthews \& Burden, 2013). Research in health topics has also helped to prove the rusticity and adaptability of donkeys under stress conditions (Svendsen, 2000). A study evaluating the behavior of the physiological parameters in Nordestino donkeys under a tropical environment demonstrated that thermoregulation mechanisms exhibit few daily cyclical variations. Therefore, the animals are not 

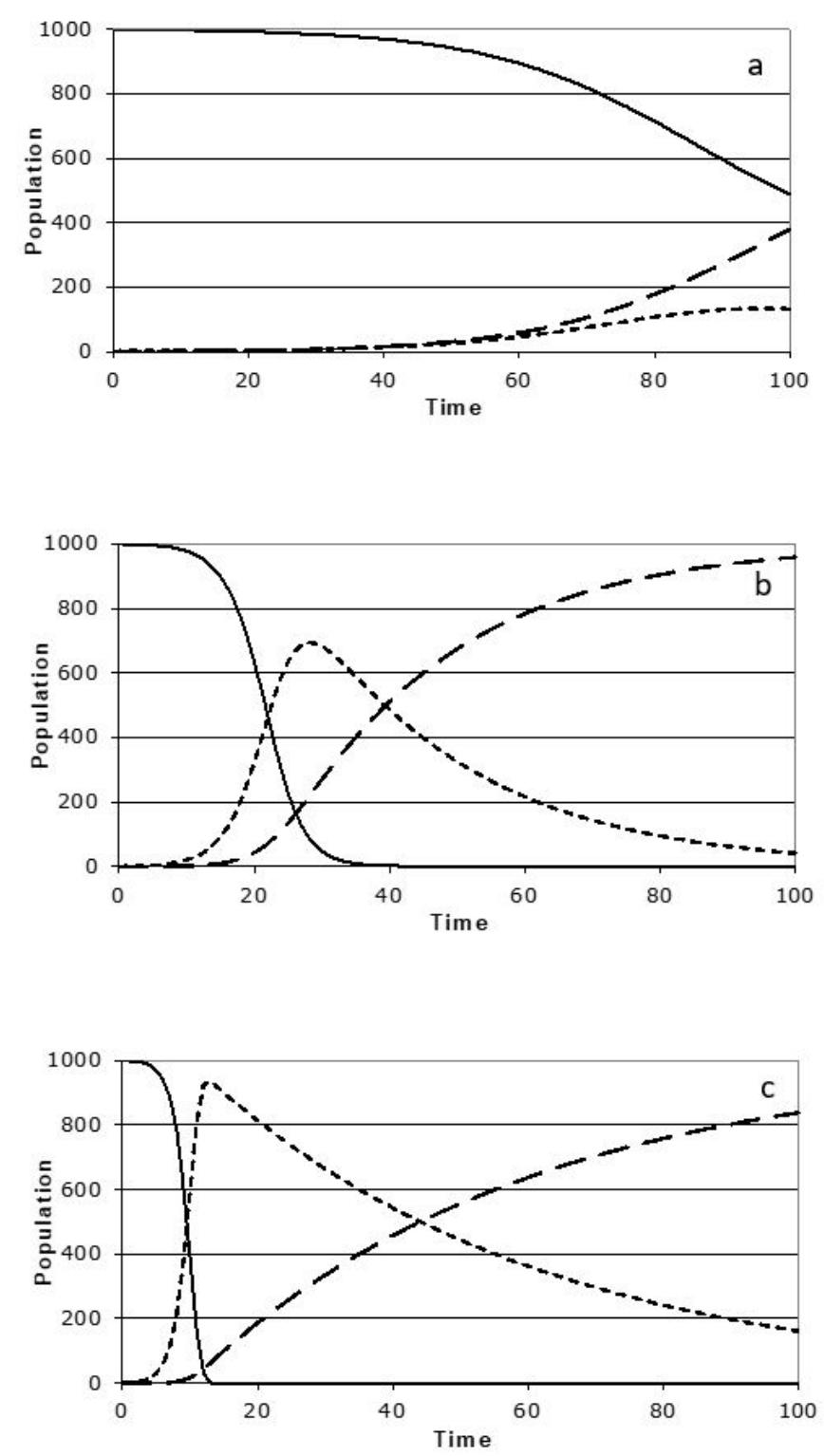

Figure 2 - SIR model for three simulated conditions based on the level of parasite infection of donkeys (refer to Table 1). Lines represent susceptible (solid line), recovered (dotted line), and infected (dashed line) individuals.

very physiologically influenced by environmental factors in high-temperature conditions in the semiarid region of Brazil (Paiva et al., 2019). According to Ayo et al. (2014), as a compensatory and adaptive mechanism, donkeys can increase their respiratory rate to lose heat through respiratory evaporation, preventing an increase in their body temperature, reestablishing body homeostasis. However, producers have to understand and accept that animals, although adapted to thermal stress, need better housing conditions to achieve their full performance. As often witnessed, donkeys are subjected to constant water and food deprivation, and these conditions still need to be studied, as well as the possible link and consequences to disease cases and the need for treatment (Valle et al., 2017).
Parasite infections fall into one of the welfare principles, which is good health or the absence of disease (Animal Welfare Indicators, 2015). In real terms, field animals are conditioned to biotic and abiotic challenges that can influence their development (i.e. immune maturity after parasite challenge). Therefore, we must consider that parasite challenge is a natural condition (Colditz \& Hine, 2016), assuming that the animals are kept under acceptable clinical, nutritional, and housing conditions to express their resilient behavior.

Vercruysse \& Claerebout (2001) defined three distinct limits for parasite control in livestock, instead of using a constant mass treatment. The "therapeutic threshold" identifies clinically infected animals; the "production threshold" measures the effects of parasitism on weight or milk production, before the disease imposes major consequences, and the "preventive threshold" predicts infection levels based on local epidemiological data. In the case of equids with all the clinical significance and performance implications, parasite control is based predominantly on preventive strategies (Canever et al., 2013), even though the negative consequence is the selection for drug resistance parasites.

Considering this difficult situation, we strongly need to establish new parasite control methods. One interesting protocol adopted in ruminants is the target selection for treatment. The individual identification of the most infected animal has been proposed for horses (Becher et al., 2010), and could be carefully implemented in donkeys to reduce the number of anthelmintic treatments and, consequently, parasite selection for resistance. Becher et al. (2010) reported a statistically significant negative correlation between the maximum and mean EPG of horses and age in Germany and Austria, indicating the possibility to apply the target selection based on EPG in adult animals. The data could also be realistically applied to donkeys, knowing the many limitations of data collections and some differences in breed resilience.

\section{Conclusion}

As donkey farming is present worldwide, we should be aware of the risk and possible health problems associated with parasite infections. It is clear from the literature that responsible health practices for donkeys must be implemented using best-practice protocols to improve the welfare condition of these animals. Also, most of the information regarding donkey dairy farming is new and still being produced.

As discussed in this article, we think that practitioners should follow this new momentum and get all the necessary preparation for field and laboratory use. Information 
from individual animals and farms, using the available questionnaires, should be compiled and interpreted to establish specific health programs. The epidemiological SIR model that was presented here, should be used to determine parasite risk factors and different scenarios, supporting credible integrative and holistic farming.

\section{References}

ABCJPêga. [Internet]. Associação Brasileira de Criadores de Jumento Pegâ: Projeto Social. 2020. [cited 2020 Oct 15]. Available from: https://abcjpega.org.br/servico/projeto-social/.

Animal Welfare Indicators - AWIN. Welfare assessment protocol for donkeys. Rome; 2015. http://dx.doi.org/10.13130/ AWIN_donkeys_2015.

Antunes JMAP, Allendorf SD, Appolinário CM, Peres MG, Perotta JH, Neves TB, Deconto I, Barros IR Fo, Biondo AW, Megid J. Serology for Brucella abortus in cart horses from an urban area in Brazil. Braz Arch Vet Med Animal Sci. 2013;65(2):619-21. http://dx.doi.org/10.1590/S010209352013000200044 .

Araújo AL, Souza GAF, Nóbrega PINo, Souza AP. Tranquilization of donkeys using acepromazine or acepromazine/diazepam. Arq Bras Med Vet Zootec. 2014;66(1):109-15. http://dx.doi. org/10.1590/S0102-09352014000100016.

Aspri M, Souroullas K, Ioannou C, Papademas P. Physicochemical composition and antimicrobial protein content of early lactation donkey milk. Int J Food Stud. 2019;8(1):6875. http://dx.doi.org/10.7455/ijfs/8.1.2019.a6.

Attia MM, Khalifa MM, Atwa MT. The prevalence and intensity of external and internal parasites in working donkeys (Equus asinus) in Egypt. Vet World. 2018;11(9):1298306. http://dx.doi.org/10.14202/vetworld.2018.1298-1306. PMid:30410237.

Ayo JO, Dzenda T, Olaifa F, Ake SA, Sani I. Diurnal and seasonal fluctuations in rectal temperature, respiration and heart rate of pack donkeys in a tropical savannah zone. J Equine Sci. 2014;25(1):1-6. http://dx.doi.org/10.1294/ jes.25.1. PMid:24834007.

Becher AM, Mahling M, Nielsen MK, Pfister K. Selective anthelmintic therapy of horses in the Federal states of Bavaria (Germany) and Salzburg (Austria): an investigation into strongyle egg shedding consistency. Vet Parasitol. 2010;171(12):116-22. http://dx.doi.org/10.1016/j.vetpar.2010.03.001. PMid:20356680.

\section{Conflict of Interest}

We declare to have no conflict of interest.

\section{Ethics Statement}

We declare to have followed all recommendation for the Ethical writing and research.

Bevilaqua CML, Rodrigues ML, Concordet D. Identification of infective larvae of some common nematode strongylids of horses. Rev. Med. Vet. 1993;144:989-95.

Bordonaro S, Dimauro C, Criscione A, Marletta D, Macciotta NPP. The mathematical modeling of the lactation curve for dairy traits of the donkey (Equus asinus). J Dairy Sci. 2013;96(6):4005-14. http://dx.doi.org/10.3168/jds.20126180. PMid:23587386.

Borioni N, Marinaro P, Celestini S, Del Sole F, Magro R, Zoppi D, Mattei F, Dall'Armi V, Mazzarella F, Cesario A, Bonassi S. Effect of equestrian therapy and onotherapy in physical and psycho-social performances of adults with intellectual disability: a preliminary study of evaluation tools based on the ICF classification. Disabil Rehabil. 2012;34(4):279-87. http://dx.doi.org/10.3109/09638288.2 011.605919. PMid:21988646.

Canever RJ, Braga PRC, Boeckh A, Grycajuck M, Bier D, Molento MB. Lack of Cyathostomin sp. reduction after anthelmintic treatment in horses in Brazil. Vet Parasitol. 2013;194(1):9-39. http://dx.doi.org/10.1016/j. vetpar.2012.12.020. PMid:23318166.

Carroccio A, Cavataio F, Montalto G, D’Amico D, Alabrese L, Iacono G. Intolerance to hydrolysed cow's milk proteins in infants: clinical characteristics and dietary treatment. Clin Exp Allergy. 2000;30(11):1597-603. http://dx.doi. org/10.1046/j.1365-2222.2000.00925.x. PMid:11069569.

Castro LL, Abrahao C, Buzatti A, Molento MB, Bastianetto E, Rodrigues DS, Lopes L, Silva MX, Freitas MG, Conde MH, Borges FA. Comparison of McMaster and Mini-FLOTAC fecal egg counting techniques in cattle and horses. Vet Parasitol Reg Stud Rep. 2017;10(1):132-5. http://dx.doi. org/10.1016/j.vprsr.2017.10.003. PMid:31014585.

Colditz IG, Hine BC. Resilience in farm animals: biology, management, breeding and implications for animal welfare. Anim Prod Sci. 2016;56(1):1961-83. http://dx.doi.org/10.1071/ AN15297. 
Coles GC, Jackson F, Pomroy WE, Prichard RK, von SamsonHimmelstjerna G, Silvestre A, Taylor MA, Vercruysse J. The detection of anthelmintic resistance in nematodes of veterinary importance. Vet Parasitol. 2006;136(3-4):167-85. http:// dx.doi.org/10.1016/j.vetpar.2005.11.019. PMid:16427201 .

Costa PWL, Feitosa TF, Vilela VLR. Parasitic profile of traction equids in the semi-arid climate of Paraíba State, Northeastern, Brazil. Rev Bras Parasitol Vet. 2018;27(2):21822. http://dx.doi.org/10.1590/s1984-296120180035. PMid:29846453.

Dai F, Dalla Costa E, Burden F, Judge A, Minero M. The development of guidelines to improve dairy donkey management and welfare. Ital J Anim Sci. 2019;18(1):18993. http://dx.doi.org/10.1080/1828051X.2018.1503571.

Dai F, Segati G, Costa ED, Burden F, Judge A, Minero M. Management practices and milk production in dairy donkey farms distributed over the Italian territory. Maced Vet Rev. 2017;40(2):131-6. http://dx.doi.org/10.1515/ macvetrev-2017-0016.

Disassa H, Alebachew A, Zenebe T, Kebede G. Prevalence of strongyle infection in horses and donkeys in and around Dangila Town, Northwest Ethiopia. Acta Parasitol Global. 2015;6(1):14-9. http://dx.doi.org/10.5829/idosi.apg.2015.6.1.9159.

Elsheikha $\mathrm{H}$. How can vets alleviate anthelmintic resistance in donkeys? [Internet]. Veterinary Practice; Swindon, England; 2019 Aug 1 [cited 2020 Nov 02]. Available from: https://veterinary-practice.com/article/how-can-vetsalleviate-anthelmintic-resistance-in-donkeys

Fantuz F, Ferraro S, Todini L, Piloni R, Mariani P, Salimei E. Donkey milk concentration of calcium, phosphorus, potassium, sodium and magnesium. Int Dairy J. 2012;24(2):143-5. http://dx.doi.org/10.1016/j.idairyj.2011.10.013.

Ferreira GMS, Dutra FAF, Amorim EF Fo, Santos ACG. Gastrointestinal parasitism and hematology in horses and donkeys from the urban área of São Luis, MA, Northeast Brazil. Arch Vet Sci. 2014;19(2):22-30.

Gianfaldoni C, Barlozzari G, Mancini S, Di Domenico E, Maestrini M, Perrucci S. Parasitological investigation in an organic dairy donkey farm. Large Anim Rev. 2020;26(1):25-30.

Gokbulut C, Aksit D, Smaldone G, Mariani U, Veneziano V. Plasma pharmacokinetics, faecal excretion and efficacy of pyrantel pamoate paste and granule formulations following per os administration in donkeys naturally infected with intestinal strongylidae. Vet Parasitol. 2014;205(1-2):186-92. http://dx.doi.org/10.1016/j.vetpar.2014.06.026. PMid:25015542.

Grosenbaugh DA, Reinemeyer CR, Figueiredo MD. Pharmacology and therapeutics in donkeys. Equine Vet Educ. 2011;23(1):523-30. http://dx.doi.org/10.1111/j.20423292.2011.00291.x.

Heesterbeek JAP, Roberts MG. Threshold quantities for helminth infections. J Math Biol. 1995;33(4):415-34. http:// dx.doi.org/10.1007/BF00176380. PMid:7714416.

Holmes AD, Elman AFSP, Smith CT, Kuzmeski JW. Composition of mares' milk as compared with that of other species. J Dairy Sci. 1947;30(6):385-95. http://dx.doi. org/10.3168/jds.S0022-0302(47)92363-1.

Imam SMA, Seri HI, Hassan T, Tigani TA, Zolain HB, Abakar AD. Therapeutic efficacy evaluation of anthelmintic activity of albendazole and ivermectin drench formulations in donkeys in Darfur, Sudan. Vet Arh. 2010;80(1):585-95.

Instituto Brasileiro de Geografia e Estatística - IBGE. Sistema IBGE de recuperação automática - SIDRA. Pesquisa da pecuária municipal: acesso online às notícias, publicações, tabelas, bancos de dados e mapas: tabela 73 [Internet]. Brasília; 2012 [cited 2020 Aug 21]. Available from: https:// sidra.ibge.gov.br/Tabela/73\#resultado

Ishii JB, Arenal A, Felix A, Yoshitani U, Beech R, Molento MB. Diagnosis of resistance alleles in codon 167 of the beta-tubulin (Cya-tbb-1) gene from third-stage larvae of horse cyathostomins. Res Vet Sci. 2017;115(1):92-5. http:// dx.doi.org/10.1016/j.rvsc.2017.01.019. PMid:28199900.

Karatosidi D, Marsico G, Tarricone S. Modern use of donkeys. Iran J Appl Anim Sci. 2013;3(1):13-7.

Lichtenfels JR, Kharchenko VA, Dvojnos GM. Illustrated identification keys to strongylid parasites (Strongylidae: Nematoda) of horses, zebras and asses (Equidae). Vet Parasitol. 2008;156(1-2):4-161. http://dx.doi.org/10.1016/j. vetpar.2008.04.026. PMid:18603375.

Love S, Murphy D, Mellor D. Pathogenicity of cyathostome infection. Vet Parasitol. 1999;85(2-3):113-22. http://dx.doi. org/10.1016/S0304-4017(99)00092-8. PMid:10485358.

Love S. Parasite-associated gastrointestinal disease. In: Mair T, Divers T, Ducharme N, editors. Manual of equine gastroenterology. 1st ed. London: WB Saunders Company; 
2002. p. 53-60. http://dx.doi.org/10.1016/B978-0-70202486-3.50007-0.

Maestrini M, Molento MB, Mancini S, Martini M, Angeletti FGS, Perrucci S. Intestinal strongyle genera in diferente typology of donkey farms in Tuscany, Central Italy. Vet Sci. 2020;7(4):195-204. http://dx.doi.org/10.3390/vetsci7040195. PMid:33276602.

Mansueto P, Iacono G, Taormina G, Seidita A, D'Alcamo A, Adragna F, Randazzo G, Carta M, Rini G, Carroccio A. Ass's milk in allergy to cow's milk protein: a review. Acta Med Mediter. 2013;29(1):153-60.

Matthews JB, Burden FA. Common helminth infections of donkeys and their control in temperate regions. Equine Vet Educ. 2013;25(9):461-7. http://dx.doi.org/10.1111/eve.12018.

Molento MB, Antunes J, Novak-Bentes R, Coles GC. Anthelmintic resistant nematodes in Brazilian horses. Vet Rec. 2008;162(12):384-5. http://dx.doi.org/10.1136/ vr.162.12.384. PMid:18359933.

Molento MB, Dutra LH, Pritsch IC, Garbin VP, Pereira AM, Gavião A, Gabriel AL, de Sousa RS, Viana JGA. Fasciola hepatica infection in cattle and the use of simulation models for endemic areas. J Helminthol. 2020;94(1):e185. http:// dx.doi.org/10.1017/S0022149X2000067X. PMid:32907641.

Molento MB. Parasite control in the age of drug resistance and changing agricultural practices. Vet Parasitol. 2009;163(3):22934. http://dx.doi.org/10.1016/j.vetpar.2009.06.007. PMid:19560869.

Molento MB. Parasite resistance on helminths of equids and management proposal's. Cienc Rural. 2005;35(6):146977. http://dx.doi.org/10.1590/S0103-84782005000600041.

Naderi Y. Appropriate mathematical models to describe the lactation curves of milk production traits of Iranian Holstein dairy cattle. Acta Sci Anim Sci. 2018;40(1):e37895. http:// dx.doi.org/10.4025/actascianimsci.v40i1.37895.

Ogbourne CP, Duncan JL. Strongylus vulgaris in the horse: its biology and veterinary importance. A review. 2nd ed. Slough: Commonwealth Agricultural Bureaux; 1985.

Oryan A, Kish GF, Rajabloo M. Larval cyathostominosis in a working donkey. J Parasit Dis. 2015;39(2):324-7. http:// dx.doi.org/10.1007/s12639-013-0313-6. PMid:26064028.

Paiva ALC, Ferreira J, Nunes TL, Mouta AN, Fernandes NS, Cavalcante JM, Barrêto RA Jr, Paula VV. Northeast Brazilian donkeys have little physiological responses influenced by tropical conditions. Biol Rhythm Res. 2019;1(1):1-11. http:// dx.doi.org/10.1080/09291016.2019.1629219.

Papini RA, Orsetti C, Sgorbini M. A controlled study on efficacy and egg reappearance period of ivermectin in donkeys naturally infected with small strongyles. Helminthologia. 2020;57(2):163-70. http://dx.doi.org/10.2478/helm-20200017. PMid:32518493.

Passantino A. Welfare issues of donkey (Equus asinus): a checklist based on the five freedoms. J Verbrauch Lebensm. 2011;6(2):215-6. http://dx.doi.org/10.1007/s00003-010-0638-3.

Paz CFR, Paganela JC, Oliveira DP, Feijó LS, Nogueira CEW. Biometric standard of traction horses in Pelotas, state of Rio Grande do Sul. Ciênc Anim. 2013;14(2):159-63. http:// dx.doi.org/10.5216/cab.v14i2.13078.

Peregrine AS, Molento MB, Kaplan RM, Nielsen MK. Anthelmintic resistance in important parasites of horses: does it really matter? Vet Parasitol. 2014;201(1-2):1-8. http:// dx.doi.org/10.1016/j.vetpar.2014.01.004. PMid:24485565.

Ragona G, Corrias F, Benedetti M, Paladini I, Salari F, Altomonte I, Martini M. Amiata donkey milk chain: animal health evaluation and milk. Ital J Food Saf. 2016;5(3):5951. http://dx.doi.org/10.4081/ijfs.2016.5951. PMid:27853717.

Rangel AHN, Galvão JGB Jr, Simplício AA, Freire RMB, Novaes LP. Aspectos composicionais e nutricionais do leite de jumenta: uma revisão. Rev Inst Laticínios Cândido Tostes. 2015;70(3):160-71. http://dx.doi.org/10.14295/22386416.v70i3.395.

Santos DW, Madeira de Carvalho LM, Molento MB. Identification of third stage larval types of cyathostomins of equids: an improved perspective. Vet Parasitol. 2018;260(1):49-52. http:// dx.doi.org/10.1016/j.vetpar.2018.08.007. PMid:30197013.

Svendsen ED. The professional handbook of the donkey. 3rd ed. London: Whittet Books; 2000.

Tavassoli M, Arjmand Yamchi J, Hajipour N. A survey on the prevalence of strongyles species in working donkeys in North-West of Iran. J Parasit Dis. 2016;40(4):1210-2. http:// dx.doi.org/10.1007/s12639-015-0651-7. PMid:27876916.

Trawford AF, Tremlett JG. Efficacy of triclabendazole against Fasciola hepatica in the donkey (Equus asinus). Vet Rec. 1996;139(6):142-3. http://dx.doi.org/10.1136/vr.139.6.142. PMid:8863404. 
Upjohn MM, Pfeiffer DU, Verheyen KL. Helping working Equidae and their owners in developing countries: monitoring and evaluation of evidence-based interventions. Vet J. 2014;199(2):210-6. http://dx.doi.org/10.1016/j. tvjl.2013.09.065. PMid:24269105.

Valle E, Raspa F, Giribaldi M, Barbero R, Bergagna S, Antoniazzi S, McLean AK, Minero M, Cavallarin L. Afunctional approach to the body condition assessment of lactating donkeys as a tool for welfare evaluation. PeerJ. 2017;5:e3001. http:// dx.doi.org/10.7717/peerj.3001. PMid:28367363.

Vercruysse J, Claerebout E. Treatment vs non-treatment of helminth infections in cattle: defining the threshold. Vet
Parasitol. 2001;98(1-3):195-214. http://dx.doi.org/10.1016/ S0304-4017(01)00431-9. PMid:11516586.

Vynnycky E, White R. Introduction to infectious disease modelling. 1st ed. Oxford: Oxford University Press; 2010.

Wise D. [Internet]. Donkey Therapy Italy - For people who love donkeys. 2020. [cited 2020 Dec 18]. Available from: https://donkeywise.org/donkey-therapy/italy/.

Financial Support: MB Molento has received partial financing from $\mathrm{CNPq} / 001$. 